\title{
Pakistan's Trade Efficiency with its Free Trade Agreements, Preferential Trade Agreements, and Major Trading Partners
}

\author{
ZULFIQAR ALI KEERYO \\ PhD Scholar, Department of Economics, Shah Abdul Latif University, Khairpur. \\ Email: zakeconomist@gmail.com \\ Prof. Dr. ASAD RAZA ABIDI \\ Professor, Department of Economics, Shah Abdul Latif University, Khairpur. \\ Email: asadabidi1448@yahoo.com
}

JAZIB MUMTAZ

Ph.D. Scholar, Shaheed Zulfikar Ali Bhutto Institute of Science and Technology, Karachi. Email: jazibkhan222@gmail.com

\begin{abstract}
Worldwide trade plays a significant part in encouraging Pakistan's economic growth and development. For further enhancing the trade, the concerned quarters or authorities have dynamically grown the number of free trade agreements with its trading nations. However, there are various reasons for the surge of RTAs/FTAs worldwide. In this study, we estimated the trade efficiency of Pakistan's exports and imports and its determinants. The stochastic gravity model was used with data from 13 countries starting from 1981 till 2018. The results suggest Pakistan's trade is much below its true potential. The trade efficiency of exports contributed more as compared to the trade efficiency of imports. The average trade efficiency of exports stands at $36 \%$ which is still lower than the potential. This implies that Pakistan needs to explore new markets and develop value-added products to achieve $100 \%$ efficiency. The average efficiency of imports of $20 \%$ reflects a lower contribution of trade within SAARC countries and others. The study further explores that reducing trade barriers and may lead to an increase in trade efficiency.
\end{abstract}

Keywords: Worldwide Trade, Pakistan's Trade Efficiency, Exports, Imports.

\section{Introduction}

The free trade agreements (FTAs) are a significant part of the regional trade agreements (RTAs). It is generally signed between two or more two countries to ease the trade (Dar, Muhammad, \& Siddiqi). Till now, Pakistan has signed three free trade agreements, three preferential trade agreements, and some regional trade agreements across the world. The main purpose of Pakistan behind these agreements is to enhance worldwide trade and foreign relations across the world. Kepaptsoglou, Karlaftis, and Tsamboulas (2010) say that free trade agreement is a tool that is widely used among nations for boosting trade, and its aim is very vivid, it is relaxing the existing constraints. Udbye (2015) says they are mutual because they are specifying the rights and obligations of both selling and buying countries. Since the early 1990s, the free trade agreements (FTAs) have become an effective instrument to increase trade among countries (Hai, Hong, Thang, \& Ngoc, 2017). European Commission in its paper describes that free trade agreements eliminate custom duties, remove quotas, reduce the number of other trade restrictions, etc. for commerce in goods and services between two or more participating nations. However, the overall determination of ending this agreement is to strengthen the homeland economy and to create employment opportunities for 
the youth of the nation due to the boost up in trade flows between the participating nations. Tan Song Chuan (2004) expresses in his paper "Challenges to multilateralism free trade agreements that these agreements could be a training platform and a knowledge-sharing opportunity for the member countries.

\section{Increment in the number of agreements}

According to the Geneva-based trade organization (WTO) online database, till August 2020, 305 free trade agreements were in force. The following table 1 shows the speedy development of free trade agreements FTAs after the turn of a hundred years. Up to 1990, 13 percent of agreements were signed in goods, 3 percent in goods and services. From 1991 to 2000, 21 percent were signed in goods and 3 percent in goods and services. From 2001 to 201039 percent were signed goods and 46 percent in goods. From 2011 to 2019, 27 percent were signed in goods and 48 percent in goods and services. However, in aggregate out of 100 percent, 8 percent were signed in up to 1990, 12 percent from 1991 to 2000, 42 percent from 2001 to 2010, and 38 percent from 2011 to 2019. In all years 152 were signed in goods and 153 in goods and services. The total number becomes 305 .

Table 1. The Position of Pacts

\begin{tabular}{|c|c|c|c|c|c|c|}
\hline \multirow{2}{*}{$\begin{array}{c}\text { Date of entry } \\
\text { into force }\end{array}$} & \multicolumn{3}{|c|}{ Number of agreements } & \multicolumn{3}{c|}{ Percentage of agreements } \\
\cline { 2 - 7 }$y$ & Goods & Goods \& Services & All & Goods & Goods \& Services & All \\
\hline Up to 1990 & 20 & 05 & 25 & 13 & 03 & 08 \\
\hline $1991-2000$ & 32 & 05 & 37 & 21 & 03 & 12 \\
\hline $2001-2010$ & 59 & 69 & 128 & 39 & 46 & 42 \\
\hline $2011-2019$ & 41 & 74 & 115 & 27 & 48 & 38 \\
\hline All Years & 152 & 153 & 305 & 100 & 100 & 100 \\
\hline
\end{tabular}

International trade plays a vital role in encouraging Pakistan's economic growth and development. For further enhancing the trade, the concerned quarters or authorities have dynamically grown the number of free trade agreements with its trading nations. In 2019, Pakistan signed the second phase of the PakistanChina FTA, and now on $1^{\text {st }}$ January 2020 becomes operational. Under this agreement, Pakistani businesses and traders have permitted to export 313 new goods on zero duty to the PRC market. Before this, under the $1^{\text {st }}$ phase of the CPFTA, 724 goods from Pakistan were allowed to export to the Chinese market at a zero rate. Now, the total number of products has become 1024 that Pakistan can export to the Chinese market. Whereas, China has permitted to export to Pakistan 6786 products at the concessionary rate of customs duty of $0 \%$. Besides, Pakistan has already signed a free trade agreement and preferential trade agreements with different countries such as Indonesia, Iran, Malaysia, Mauritius, and Sri Lanka (Government of Pakistan, Ministry of Commerce, 2020).

\section{Reasons for the surge of RTAs}

However, there are various reasons for the surge of RTAs/FTAs worldwide, but one of the most important reasons is that it has made trade easy among the nations. Secondly, through this, the countries have liberalized foreign direct investment and transfer the technology to another country. Due to the transfer of technology, the productivity of nations has improved to some extent.

\section{Literature Review}

Uzair and Nawaz (2020) evaluate Pakistan's free trade agreements implicitly with its major trading partners and explicitly with China, by employing the augmented gravity techniques and data of 32 years (1996- 
2018). They find that compared to China, Malaysia, and Sri Lanka FTAs are less effective for Pakistan. They suggest that in the next round of negotiation, the government should focus that the Chinese government should consider the provision of market access to Pakistani exporters.

Gul and Yasin (2011) analyze the trade potential of Pakistan with worldwide and specific trading regions, by employing the gravity model and data of 24 years (1981-2005). They find that Pakistan's trade potential with Asia Pacific Region, EU, ME, LA, and NA is the highest, and maximum trade potential occurs with Malaysia, Japan, Bangladesh Sri Lanka, and Denmark. They suggest that Pakistan should concentrate on trading regions such as ASEAN, ME, and EU, and to try to improve their market share.

State Bank of Pakistan (2005) conducted a study to examine the trade potential of Pakistan with its trading countries, by utilizing the gravity model and data of fifteen sectors from 2002 to 2003 . The results indicate that Pakistan and India have significant scope for expanding trade, but due to conflict between the two countries, their trade is not up to the mark even there is the great potential between them. The report also shows that textile, leather, chemicals, food beverage, and tobacco products have great potential.

Irshad et al. (2017) studied strengths weaknesses opportunities and threats analysis of the Pakistan and China Free Trade Agreement (PCFTA) and tried to find out the advantages and disadvantages of the pact by utilization of the data of 12 years (2003 to 2015). They found that Pakistan trade pattern has improved due to the FTAs but still Pakistan trade deficit is high. They have also suggested that Pakistan concerned stakeholders should concentrate on manufacturing goods and its quality and they can get a big advantage of the China consumer market.

Irshad et al. (2018) evaluate Pakistan's bilateral trade potential with China by applying the gravity model and data of 23 years (1992-2015). For getting unbiased results, they employing various estimation techniques. They found that Pakistan's trade with all FTA countries is positively affected by gross domestic products, religion, TWO, trade openness in both countries, and the common border and negatively affected by geographical distance and inflation. They also find that the overall preferential trade agreement effect is negative and highly significant. However, the trade potential of Pakistan and China is immense. They suggest that the Pakistani exporters should adopt new technology to increase and diversify exports to China.

The above-given studies use the conventional gravity model developed by Tinbergen in 1962. Both Anderson and Wincoop in 2003 stated the estimates of the Tinbergen model could be biased because this model cannot control the resistance to trade i.e. distance and official constraints to trade. Baier and Bergstrand (2009) say the biggest number of them are tough to quantify so that they are added into the unobserved error term. Our study uses the stochastic frontier gravity model.

\section{Data and Research Methodology: Stochastic Frontier Gravity Model and Trade Efficiency}

This research study focuses on the gravity model covering the countries to whom Pakistan has signed free trade agreement (FTA) such as over the period 2003 to 2018 based on both theoretical and empirical literature elaborated earlier, this research examined the impact of the integration of SAARC region on exports of Pakistan. For this purpose, an extended version of the gravity model is employed to understand the impact of FTAs. The established form of the model estimates the impact of independent variables on the dependent variable. The model also provides the possible points of the highest level which can arise due to multiple trade barriers. These barriers create a gap between actual and maximum trade which is estimated through disturbance terms having non zero and non-negative mean. Kalirajan and Findlay (2005) develop a model based on the concept of production possibility frontier. The model explores the highest possible potential for the trade without any form of trade barriers. Armstrong (2007) proposes the stochastic frontier gravity equation as follows: 


$$
X i t=f(Y i t ; \beta) \exp (v i t-u i t)
$$

The variable $\mathrm{Xit}$ is the dependent variable of bilateral trade between Pakistan and its trading partner i, $\mathrm{f}(\mathrm{Yit}$, $\beta$ ) shows the variables which affect the potential trade (Yit) without trade barriers. Both Uit and Vit are disturbance terms. Uit is used to estimate the technical inefficiency whereas Vit is used to assess the impact on trade of the rest of the variables. The value Uit should be between 0 and 1 with normal distribution having a mean of $\mu$ at $\sigma \mu 2$. The value of Vit is used to estimate the measurement and specification error.

\section{The Model is assign as follows}

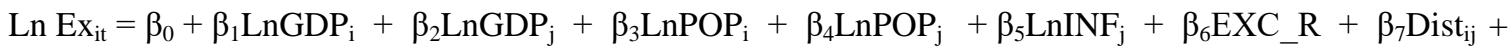
$\beta_{8}$ FTA $+\beta_{9} \mathrm{CP}+\beta_{10} \mathrm{Rlg}+\beta_{11} \mathrm{Lng}+\mathrm{V}_{\mathrm{it}}-\mu_{\text {it }}$

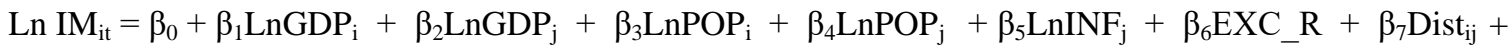
$\beta_{8} \mathrm{FTAi}+\beta_{9} \mathrm{CPi}+\beta_{10} \mathrm{Rlgi}+\beta_{11}$ Lngi $+\mathrm{V}_{\mathrm{it}}-\mu_{\mathrm{it}}$ $--(3)$

The variables EXit and IMit are actual exports and imports of Pakistan at year t respectively; GDPi and GDPj are the gross domestic product of Pakistan and its trading partners. Distij can be used to employ a distance variable between Pakistan and trading partners. FTA is a dummy variable, taking value 1 if the country has FTA with another trading partner 0 otherwise; CPi is defined as colonial past of country $\mathrm{i}$ and Pakistan; POPi and POPj capture the population of country $\mathrm{i}$ and Pakistan respectively. Rlg is having common religion of country $i$ and Pakistan. Lng is having a common language of country $i$ and Pakistan. Error term vit is the measurement and specification. Error term $\mu$ it represents negative effects on the trade volume because of man-made trade barriers and measure the size of the inefficiency of Pakistan's trade with country i.

\section{Result Estimation \& Discussion}

Figure 1. The trend of Pakistan's trade efficiencies

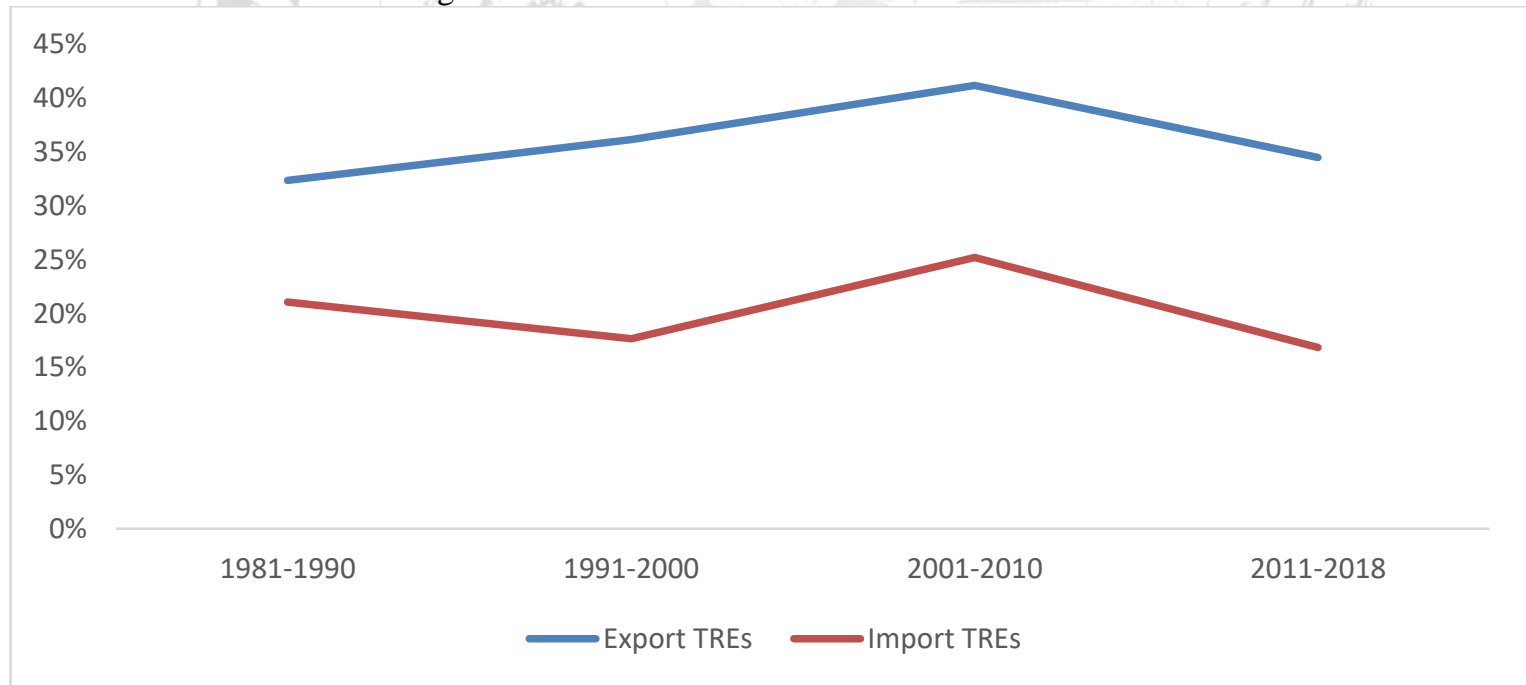

The above Figure represents the trade efficiencies of Pakistan's exports and imports for the last 37 years. The trend suggests both exports and imports are lagging behind their true potential, whereas the decline in TREs of imports is greater than the decline in TREs of exports. 
Table 2. Estimated Efficiencies of Pakistan's exports with trading partners

\begin{tabular}{|c|c|c|c|c|}
\hline Countries & $\mathbf{1 9 8 1 - 1 9 9 0}$ & $\mathbf{1 9 9 1 - 2 0 0 0}$ & $\mathbf{2 0 0 1 - 2 0 1 0}$ & $\mathbf{2 0 1 1 - 2 0 1 8}$ \\
\hline Bangladesh & $72 \%$ & $73 \%$ & $78 \%$ & $82 \%$ \\
\hline China & $20 \%$ & $11 \%$ & $21 \%$ & $30 \%$ \\
\hline Egypt & $2 \%$ & $15 \%$ & $21 \%$ & $18 \%$ \\
\hline India & $22 \%$ & $24 \%$ & $30 \%$ & $23 \%$ \\
\hline Iran & $42 \%$ & $14 \%$ & $10 \%$ & $2 \%$ \\
\hline Malaysia & $18 \%$ & $30 \%$ & $35 \%$ & $34 \%$ \\
\hline Maldives & $20 \%$ & $26 \%$ & $27 \%$ & $23 \%$ \\
\hline Mauritius & $56 \%$ & $46 \%$ & $49 \%$ & $19 \%$ \\
\hline Nepal & $3 \%$ & $9 \%$ & $5 \%$ & $1 \%$ \\
\hline Sri Lanka & $70 \%$ & $73 \%$ & $70 \%$ & $64 \%$ \\
\hline Turkey & $33 \%$ & $42 \%$ & $58 \%$ & $37 \%$ \\
\hline United Kingdom & $49 \%$ & $72 \%$ & $76 \%$ & $77 \%$ \\
\hline United States & $14 \%$ & $35 \%$ & $54 \%$ & $37 \%$ \\
\hline
\end{tabular}

Source: author's calculation

The above table estimates the trade efficiency of Pakistan's exports with its trading partner. The trend suggests that average trade efficiency increases in the current decade compared to previous years. A prominent increase can be witnessed in trade efficiency with China due to the removal of trade barriers. However, it still has more potential to grow and to reach $100 \%$ in the longer run. Trade efficiency with the US has increased from previous years but still has a high potential to grow. The trade efficiencies with neighbor countries have not been at its potential. Exports have high potential with India and Iran which can be tapped in the longer run.

The results conclude that exports are still far behind their actual potential. The government should undertake various policy decisions to improve export potential. Trade among SAARC countries can play a vital role in export growth.

Table 3. Estimated Efficiencies of Pakistan's Imports with trading partners

\begin{tabular}{|c|c|c|c|c|}
\hline Countries & $\mathbf{1 9 8 1 - 1 9 9 0}$ & $\mathbf{1 9 9 1 - 2 0 0 0}$ & $\mathbf{2 0 0 1 - 2 0 1 0}$ & $\mathbf{2 0 1 1 - 2 0 1 8}$ \\
\hline Bangladesh & $45 \%$ & $15 \%$ & $23 \%$ & $12 \%$ \\
\hline China & $21 \%$ & $19 \%$ & $32 \%$ & $26 \%$ \\
\hline Egypt & $4 \%$ & $6 \%$ & $19 \%$ & $34 \%$ \\
\hline India & $6 \%$ & $23 \%$ & $81 \%$ & $57 \%$ \\
\hline Iran & $28 \%$ & $52 \%$ & $64 \%$ & $21 \%$ \\
\hline Malaysia & $57 \%$ & $47 \%$ & $66 \%$ & $4 \%$ \\
\hline Maldives & $4 \%$ & $2 \%$ & $1 \%$ & $1 \%$ \\
\hline Mauritius & $2 \%$ & $1 \%$ & $6 \%$ & $54 \%$ \\
\hline Nepal & $5 \%$ & $8 \%$ & $1 \%$ & $0 \%$ \\
\hline Sri Lanka & $64 \%$ & $30 \%$ & $32 \%$ & $8 \%$ \\
\hline Turkey & $29 \%$ & $23 \%$ & $0 \%$ & $1 \%$ \\
\hline United Kingdom & $5 \%$ & $2 \%$ & $2 \%$ & $0 \%$ \\
\hline United States & $3 \%$ & $0 \%$ & $0 \%$ & 0 \\
\hline
\end{tabular}

Source: author's calculation

Table 3 estimates the trade efficiency of Pakistan's imports with its trading partner. The trend suggests that average trade efficiency has remained concentrated with few countries in the current decade compares to 
previous years. The prominent increase can be witnessed in trade efficiency with India which can be attributed to the lower distance and lower costs. Egypt and Mauritius also have shown growth over the years. However, Imports from India have vast potential to grow provided lower trade barriers. Iran is also an important destination for trade due to its proximity and lower cost.

Table 4. Determinants of Trade Efficiency

\begin{tabular}{|c|c|c|}
\hline Variables & TRE Exports & TRE Imports \\
\hline \multirow[t]{2}{*}{ FTA } & -2.592 & -16.775 \\
\hline & $(0.000)^{* * *}$ & $(0.000)^{* * *}$ \\
\hline \multirow[t]{2}{*}{ Common Religion } & -1.602 & -9.31768 \\
\hline & $(0.000)^{* * *}$ & $(0.002)^{* * *}$ \\
\hline \multirow[t]{2}{*}{ Common Language } & -2.636 & -14.7136 \\
\hline & $(0.000)^{* * *}$ & $(0.001)^{* * *}$ \\
\hline \multirow[t]{2}{*}{ Colonial Past } & -227.515 & 1.362206 \\
\hline & $(0.021)^{* * *}$ & $(0.551)$ \\
\hline \multirow[t]{2}{*}{ Distance } & -1.352 & 10.24875 \\
\hline & $(0.000)^{* * *}$ & $(0.000)^{* * *}$ \\
\hline \multirow[t]{2}{*}{ Constant } & 13.904 & -75.642 \\
\hline & $(0.000)^{* * *}$ & $(0.001)^{* * *}$ \\
\hline \multicolumn{3}{|c|}{ Note: numbers in parentheses are a probability. } \\
\hline \multicolumn{3}{|c|}{$* * *$ significance at the $1 \%$ level, $* *$ significance at the $5 \%$ level Table- 4} \\
\hline
\end{tabular}

Table 4 shows the regression results. The estimated coefficient of FTAs is 2.592 for exports and -16.775 for imports respectively and all statistically significant at $1 \%$ level. The estimates suggest that FTA contributes positively to Pakistan's trade efficiency. The estimated coefficients of having common religion among trading partners are -1.602 for exports and -9.3176 from imports. The estimates suggest that common religion decreases trade inefficiency and is significant at $1 \%$ level. The other estimates of having a common language also decrease trade inefficiency by -227.51 for exports and significant at $1 \%$ level but for imports the estimates are insignificant. The coefficient of distance among trading partners for exports decreases trade inefficiency by -1.352 but increases inefficiency by 10.248 for imports respectively and results remain significant at $1 \%$ level.

\section{Conclusion}

In this paper, we estimated the trade efficiency of Pakistan's exports and imports and its determinants. The stochastic gravity model was used with data from 13 countries starting from 1981 till 2018. The results suggest Pakistan's trade is much below its true potential. The trade efficiency of exports contributed more as compared to the trade efficiency of imports. The average trade efficiency of exports stands at $36 \%$ which is still lower than the potential. This implies that Pakistan needs to explore new markets and develop valueadded products to achieve $100 \%$ efficiency. The average efficiency of imports of $20 \%$ reflects a lower contribution of trade within SAARC countries and others.

The study further explores that reducing barriers to trade and removing duties may lead to an increase in trade efficiency. The distance among trading countries also impacts trade efficiency. Higher distance may increase trade inefficiency and vice versa. Common language and religion also reduce trade inefficiency as countries of the same religion and language tend to trade more. To improve trade efficiency Pakistan should join more PTAs and FTAs, remove non-tariff barriers, and improve product development. 


\section{References}

Acharya, R. (2016). Introduction. Regional Trade Agreements: Recent Developments. In R. Acharya (Ed.), Regional Trade Agreements, and the Multilateral Trading System (pp. 1-17). Cambridge, UK: Cambridge University Press/World Trade Organization.

Armstrong, S. (2007). Measuring Trade and Trade Potential: A Survey. Asia Pacific Economic Papers, No. 368, 1-19. https://doi.org/10.2139/ssrn.1760426.

Chuan, T. S. (2004). Challenges to multilateralism free trade agreements. Asia Europe Journal, 121-132.

Dar, A. A., Muhammad, T., \& Siddiqi, M. W. (2004). Impact of South-South Trade Agreement on Exports of Pakistan.

Government of Pakistan, Ministry of Commerce. (2020). Trade Agreements. Retrieved from http://www.commerce.gov.pk/about-us/trade-agreements/

Gul, N., \& Yasin, H. M. (2011). The Trade Potential of Pakistan: An Application of the Gravity Model. The Lahore Journal of Economics, 23-62.

Hai, Hong, N. T., Thang, \& Ngoc, D. (2017). The ASEAN Free Trade Agreement and Vietnam's Trade Efficiency. Asian Social Science.

Irshad, M. S., Xin, Q., Hao, H., \& Arshad, H. (2017). SWOT ANALYSIS OF PAKISTAN-CHINA FREE TRADE AGREEMENT: PROS AND CONS. International Journal of Asian Social Science, 45-53.

Irshad, M. S., Xin, Q., Hui, Z., \& Arshad, H. (2018). An empirical analysis of Pakistan's bilateral trade and trade potential with China: A gravity model approach. Cogent in Economics \& Finance.

Kalirajan, K., \& Findlay, C., (2005). Estimating Potential Trade Using Gravity Models: A Suggested Methodology. Foundation for Advanced Studies on International Development, Tokyo.

Kepaptsoglou, K., Karlaftis, M. G., \& Tsamboulas, D. (2010). The Gravity Model Specification for Modeling International Trade Flows and Free Trade Agreement Effects: A 10-Year Review of Empirical Studies. The Open Economics Journal, 1-13.

State Bank of Pakistan. (2005). Special Section 7.5: Pakistan's Export Potential: A Gravity Model Analysis. In the Annual Report 2004-05. Karachi. Karachi: State Bank of Pakistan.

Udbye, A. (2015). How did the U.S. Free Trade Agreements fare? A comparative study of export, import, and bilateral growth rates for the twenty countries before and after the FTA's. US West Chapter Conference (p. 20). Seattle: University of Puget Sound.

Uzair, L., \& Nawaz, A. (2020). The Epoch of Free Trade Agreements in Pakistan and Predominance of China. The Chinese Economy. 